\author{
YARA EL KHOURY $(*)(* *)$ - MONICA ORESTE $(* *)$ - ELISE NOUJEIM $(*)$ - NABIL NEMER $(* * *)$ \\ EUSTACHIO TARASCO $(* *)$
}

\title{
EFFECT OF TEMPERATURE ON THE PATHOGENICITY OF MEDITERRANEAN NATIVE ENTOMOPATHOGENIC NEMATODES (STEINERNEMATIDAE AND HETERORHABDITIDAE) FROM NATURAL ECOSYSTEMS
}

\author{
(*) National Center for Marine Sciences, National Council for Scientific Research-CNRS, P.O.Box 11-8281, Ryad El Solh \\ 1107 2260, 59, Zahia Selman Street, Beirut, Lebanon \\ (**) Dipartimento di Scienze del Suolo, della Pianta e degli Alimenti (Di.S.S.P.A.), Università degli Studi di Bari 'Aldo \\ Moro',Via Amendola 165/A, 70126 Bari, Italy; email: yara.elkhoury@uniba.it \\ (***) Holy Spirit University of Kaslik, Faculty of Agricultural and Food Sciences, PO Box 446, Jounieh, Lebanon
}

El Khoury Y., Oreste M., Noujeim E., Nemer N., Tarasco E. - Effect of temperature on the pathogenicity of Mediterranean native entomopathogenic nematodes (Steinernematidae and Heterorhabditidae) from natural ecosystems.

Seven strains of entomopathogenic nematodes (EPNs) belonging to three species (Steinernema feltiae, S. ichnusae and Heterorhabditis bacteriophora) naturally isolated from Mediterranean countries (Southern Italy and Lebanon) were evaluated for their potential to infest greater wax moth (Galleria mellonella) larvae at different temperatures under laboratory conditions. The laboratory bioassay was conducted at six different temperatures ranging from $10^{\circ} \mathrm{C}$ to $35^{\circ} \mathrm{C}$. Nematode Infective Juvenile (IJs) were put in contact with G. mellonella larvae in Petri dishes and mortality rates were recorded after 72 hours. The purpose of the study was to evaluate the temperature range in which the EPNs caused larval mortality; higher mortalities were recorded at $15^{\circ} \mathrm{C}$ and $20^{\circ} \mathrm{C}$. All species failed at lower temperatures except for $S$. ichnusae ItS-SAR4, which caused $7 \%$ mortality. At $35^{\circ} \mathrm{C} S$. ichnusae maintained its infectious activity (24\%) along with H. bacteriophora ItH-LU1 (38\%); both were isolated from Italy and were more efficient at high temperatures than the remaining Lebanese isolates.

Key WoRDs: Steinernema feltiae, Steinernema ichnusae, Heterorhabditis bacteriophora, Mediterranean Habitats, temperature, bioassay.

\section{INTRODUCTION}

Entomopathogenic nematodes (EPNs) in the Steinernematidae and Heterorhabditidae families are obligate parasites to wide range of insect pests (EHLERS, 2001; LACEY et al., 2015) but known as efficient biological control mostly for soil-dwelling insects (POINAR, 1990). Pathogenicity of EPNs is dependent on several biotic and abiotic conditions. Moreover, soil temperature can also affect the activity of entomopathogenic nematodes representing a barrier against their success as biocontrol agents. In fact, it may affect the ability of entomopathogenic nematodes to infest their host (GRIFFIN \& Downes 1991; Kung et al., 1991; Molyneux, 1985,1986; TARASCO, 1997; TARASCO et al., 2015b) and to develop and reproduce (KayA, 1977; Dunphy \& Webster, 1986; Zervos et al., 1991; GREWAL et al., 1994). EPNs are naturally found in the soil and have a wide geographical distribution around the world. Their optimal temperatures for infection and reproduction may vary among nematode species and isolates (GREWAL et al., 1994). In general, temperatures below $0^{\circ} \mathrm{C}$ and above $37^{\circ} \mathrm{C}$ are lethal to most of these entomopathogens (GrEWAL et al., 1994; GRIFFIN, 1993; UlU \& SUSURLUK, 2014) while temperatures below $10-15^{\circ} \mathrm{C}$ can limit their mobility. However, despite the adaptation of some species to warm climate, others can maintain their pathogenicity also at low temperatures ( WRIGHT, 1992; GREWAL et al., 1994; BERRY et al., 1997).

In order to enhance the efficiency of EPNs as biological control agents and ensure the success of the control, an adequate selection of strains according to their ability to infest under different temperatures is mandatory (YEO et al. 2003). Accordingly, the present study aims to evaluate the effect of different temperature on the pathogenicity of seven native Mediterranean EPNs strains isolated from natural ecosystems in Italy (TARASCO et al., 2015a; TARASCO \& Triggiani, 1997) and Lebanon (NoujeIM et al., 2016) and to compare the pathogenicity of these isolates.

\section{MATERIALS AND METHODS}

\section{ENTOMOPATHOGENIC NEMATODES}

Bioassays were carried out with isolates of seven strains of EPNs belonging to: S. feltiae Filipjev, 1934 (4 strains from Lebanon: EHB1, EDA1, EHB5, EHB4); S. ichnusae Tarasco et al., 2008 (one strain from Italy ItS-SAR4); $H$. bacteriophora Poinar, 1976 (Italian strain ItH-LU1) and Heterorhabditis sp. (Lebanese strain BAR8) (Table 1). EPNs were collected using the "Galleria baiting technique" (BEDDING , 1975) during a soil survey in different habitats in Italy (TARASCO et al., 2015a; TARASCO \& TRIGGIANI, 1997) and Lebanon (NoujeIM et al., 2016). To obtain fresh infective juveniles (IJs), nematodes were inoculated in last instar Galleria mellonella (Lepidoptera, Pyralidae) larvae at a temperature of $22 \pm 2{ }^{\circ} \mathrm{C}$ on a $100 \times 10 \mathrm{~mm}$ Petri dish with one $90 \mathrm{~mm}$ filter treated with 2,000 IJs in 1,5 ml of water, as described by TARASCO et al., (2015b). Dead last instar 
Table 1 - Characteristics of the locations of isolated Mediterranean EPNs

\begin{tabular}{lccccc}
\hline \hline Strain & Locality & $\begin{array}{c}\text { Altitude } \\
(\mathbf{m} . \mathbf{a . s} . \mathbf{)})\end{array}$ & Ecosystem & Soil texture & $\begin{array}{c}\text { Avg Temp } \\
\left({ }^{\circ} \mathbf{C}\right)\end{array}$ \\
\hline S. feltiae EDA1 & Edde-Lebanon & 200 & Agriculture (Potatoes) & Sandy loamy & 19.2 \\
\hline S. feltiae EHB5 & Ehmej-Lebanon & 1140 & Cedars (rivers' border) & Sandy & 16.3 \\
\hline S. feltiae EHB4 & Ehmej-Lebanon & 1140 & Cedars (rivers' border) & Sandy & 16.3 \\
\hline S. feltiae EHB1 & Ehmej-Lebanon & 1140 & Cedars (rivers' border) & Sandy & 16.3 \\
\hline S. ichnusae ItS-SAR4 & Platamona (SS)-Italy & 10 & Sea coast & Sandy & 19.9 \\
\hline H. bacteriophora ItH-LU1 & Lucera (FG) Italy & 70 & Uncultivated land & Clay loamy & 15.4 \\
\hline Heterorhabditis. sp. BAR8 & Baskinta- Lebanon & 1300 & Pine & Loamy & 13.8 \\
\hline
\end{tabular}

m.a.s.l Metres above sea level; FG Foggia; SS Sassari; Avg Temp $\left({ }^{\circ} \mathrm{C}\right)$ Average annual temperature obtained from www.wunderground.com

larvae were put on modified White traps (WHITE, 1927); juveniles emerging from Galleria cadavers were collected and used in bioassays within 24 hours.

\section{INFECTIVITY BIOASSAYS AT DIFFERENT TEMPERATURES}

The pathogenicity of $S$. feltiae, S. ichnusae, Heterorhabditis sp., and $H$. bacteriophora strains was tested under six temperatures ranging between $10^{\circ} \mathrm{C}$ to $35^{\circ} \mathrm{C}$ at intervals of $5^{\circ} \mathrm{C}$. For every strain, plastic boxes $(95 \times 32$ $\mathrm{mm}$ ) filled with approximately $40 \mathrm{~g}$ of sterilized peat $(75 \%$ degree of humidity) were inoculated with 1000 IJs in $1 \mathrm{ml}$ of water each. Ten G. mellonella final instars larvae (100 IJs/larva) were enclosed in each box. For each treatment 3 replicates were considered and 3 boxes without nematodes were used as control for each species and temperature. The bioassays were repeated 3 times. Larval mortality was recorded after 72 hours of exposure to IJs. Cadavers, afterwards were removed from the boxes, rinsed in tap water and dissected to confirm the presence of nematodes.

\section{STATISTICS}

The statistical program used to perform the analysis was SPSS Statistics (version 22). Data were analyzed using a general linear model procedure (ANOVA - analysis of variance) and significant differences among means were separated by HSD Tukey's test. The minimum level of significance was taken as $\mathrm{p}<0.05$.

\section{RESULTS}

Statistical analysis of mean larval mortality caused by EPNs at various temperatures showed that insect mortality was affected by temperature and strains. On the contrary, no mortality was recorded in the controls.

$-10^{\circ} \mathrm{C}$ : Steinernema ichnusae gave the best result $(7 \%$ of larval mortality) which was statistically different from all the remaining EPNs $(\mathrm{F}=4 ; \mathrm{df}=7 ; \mathrm{P}=0.01), S$. feltiae strains EHB1, EHB4, EHB5, EDA1 and H. bacteriophora ItHLU1 and Heterorhabditis sp. BAR8 caused no mortality $(0 \%)$ (Fig. I).

$-\mathbf{1 5}^{\circ} \mathrm{C}$ : Steinernema feltiae EDA1 produced the highest larval mortality percentage $(100 \%)$ which was not significantly different from the larval mortalities scored by S. feltiae EHB1, EHB4, EHB5 and Heterorhabditis sp. BAR8 that ranged from $90 \%$ to $97 \%(\mathrm{~F}=133.7$; $\mathrm{df}=7 ; \mathrm{P}=$ 0.001). Steinernema ichnusae and H. bacteriophora had lower percentages, $27 \%$ and $47 \%$ respectively (Fig. II). $-20^{\circ} \mathrm{C}$ : All Steinernema strains caused high larval mortality percentages $(>95 \%)(\mathrm{F}=211.1 ; \mathrm{df}=7 ; \mathrm{P}=$ $0.001)$, except for $S$. ichnusae ItS-SAR4 (77\%) and $H$. bacteriophora $(74 \%)$; mortality rates caused by ItS-SAR4 and ItH-LU1 were not significantly different (Fig. III).

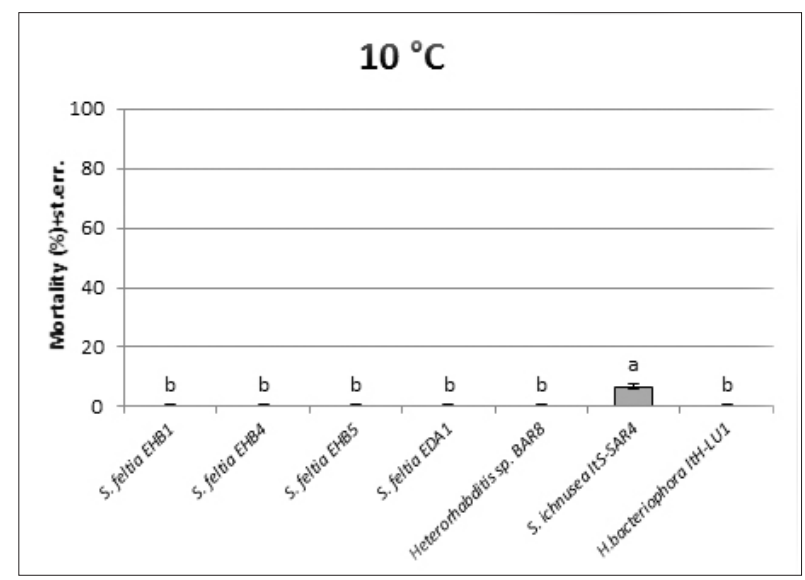

Fig. I - Pathogenicity comparison among seven native Mediterranean EPN strains: percentage mortality of $G$. mellonella larvae following $72 \mathrm{hrs}$ of exposure to IJs at $10^{\circ} \mathrm{C}$. Different letters above the bars indicate significant differences $(\mathrm{P}<0.05)$.

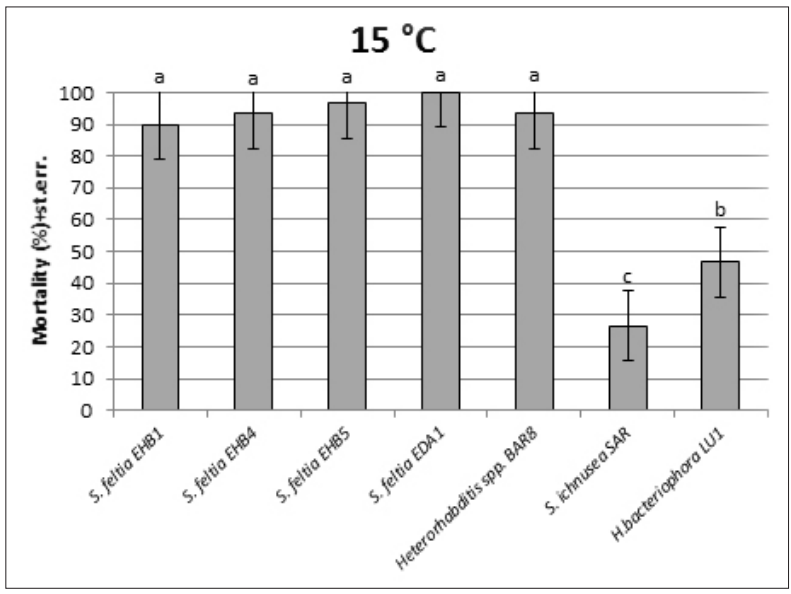

Fig. II - Pathogenicity comparison among 7 native Mediterranean EPN strains: percentage mortality of $G$. mellonella larvae following $72 \mathrm{hrs}$ of exposure to IJs at $15^{\circ} \mathrm{C}$. Different letters above the bars indicate significant differences $(\mathrm{P}<0.05)$. 


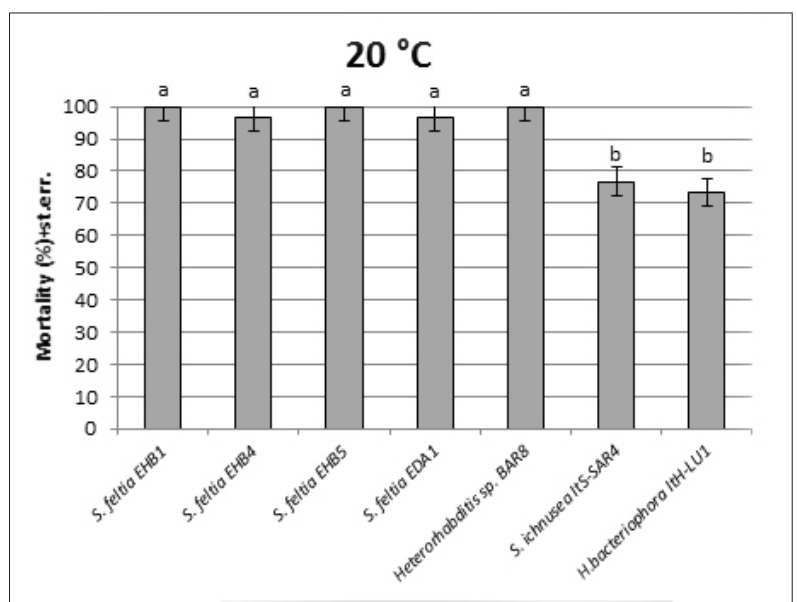

Fig. III - Pathogenicity comparison among 7 native Mediterranean EPN strains: percentage mortality of $G$. mellonella larvae following $72 \mathrm{hrs}$ of exposure to IJs at $20^{\circ} \mathrm{C}$. Different letters above the bars indicate significant differences $(\mathrm{P}<0.05)$.

$-\mathbf{2 5}^{\circ} \mathrm{C}$ : Almost all strains of S. feltiae killed about $90 \%$ of Galleria larvae except for EHB5 that caused 77\% larval mortality, while H. bacteriophora caused $100 \%$ Galleria larvae mortality. Steinernema ichnusae and Heterorhabditis sp. BAR8 killed around $87 \%(\mathrm{~F}=46.5 ; \mathrm{df}=7 ; \mathrm{P}=0.001)$ (Fig. IV).

$-\mathbf{3 0}^{\circ} \mathrm{C}$ : Steinernema feltiae strain EHB4 induced the highest mortality $(97 \%)$ which was statistically different from the result given by the other $S$. feltiae strain EDA1 (57\%); the remaining $S$. feltiae strains followed with lower larval mortality percentages $33 \%$ and $46 \%(\mathrm{~F}=6 ; \mathrm{df}=7 ; \mathrm{P}=0.001)$. Heterorhabditis bacteriophora ItH-LU1 gave 74\% larval mortality which was not statistically different from S. ichnusae (53\%) and Heterorhabditis sp. BAR8 (60\%) (Fig. V).

$-\mathbf{3 5}^{\circ} \mathrm{C}$ : Heterorhabditis bacteriophora ItH-LU1 presented the highest larval mortality percentage (37\%) statistically different from $S$. ichnusae which induced mortality of $24 \%$; no mortality was recorded for the remaining strains $(\mathrm{F}=74$; $\mathrm{df}=7 ; \mathrm{P}=0.001)($ Fig. VI).

\section{DISCUSSION AND CONCLUSION}

Soil is the natural habitat of EPNs, it protects them from harmful environmental conditions such as extreme temperatures and low moisture levels (KUNG et al., 1991;

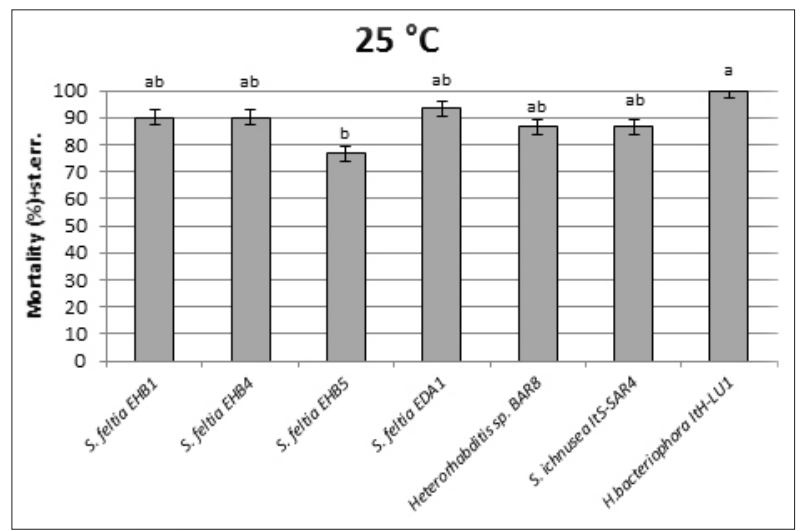

Fig. IV - Pathogenicity comparison among 7 native Mediterranean EPN strains: percentage mortality of $G$. mellonella larvae following $72 \mathrm{hrs}$ of exposure to IJs at $25^{\circ} \mathrm{C}$. Different letters above the bars indicate significant differences $(\mathrm{P}<0.05)$.

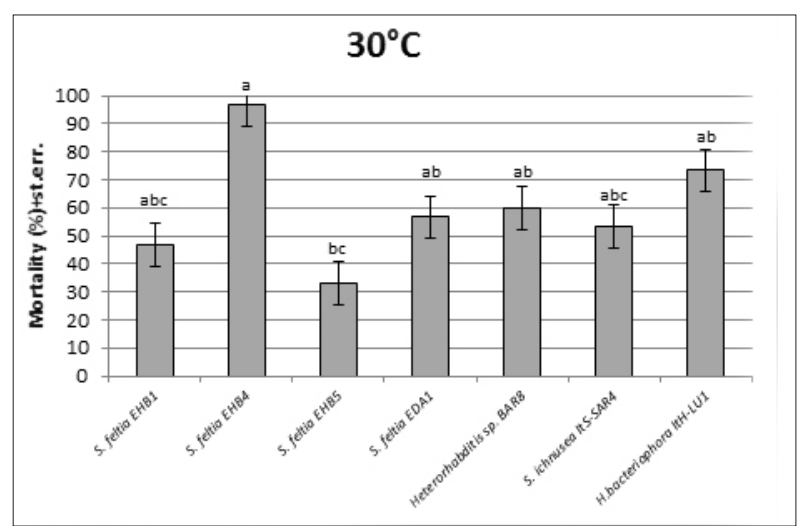

Fig. V - Pathogenicity comparison among 7 native Mediterranean EPN strains: percentage mortality of G. mellonella larvae following $72 \mathrm{hrs}$ of exposure to IJs at $30^{\circ} \mathrm{C}$. Different letters above the bars indicate significant differences $(\mathrm{P}<0.05)$.

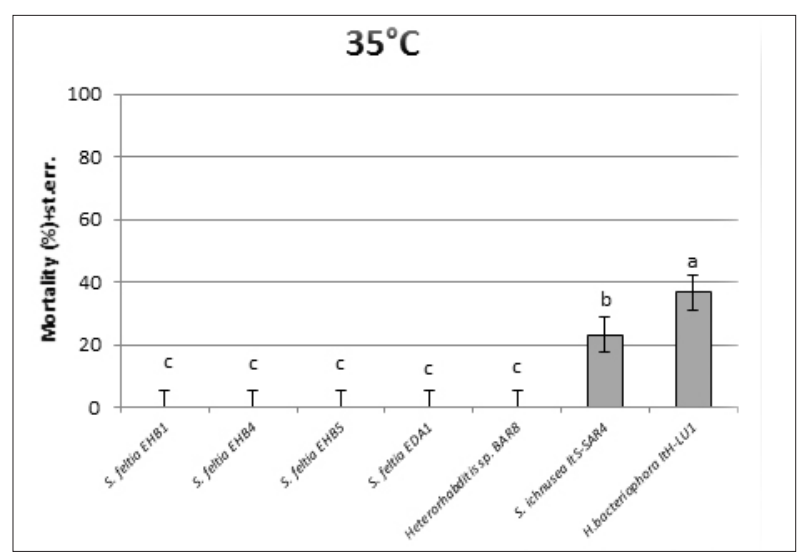

Fig. VI - Pathogenicity comparison among 7 native Mediterranean EPN strains: percentage mortality of $G$. mellonella larvae following $72 \mathrm{hrs}$ of exposure to IJs at $35^{\circ} \mathrm{C}$. Different letters above the bars indicate significant differences $(\mathrm{P}<0.05)$.

GREWAL et al., 2001). Their failure as efficient and effective biocontrol agents may be due to the interaction of different factors affecting the performance of EPNs, such as ultraviolet radiation, extreme temperatures and low moisture resulting in desiccation (RUTHERFORD et al., 1987; SHAPIRO-ILAN et al., 2006). The aim of this study was to determine the pathogenicity of Mediterranean native entomopathogenic nematode species and strains under different temperatures. All strains were able to kill Galleria larvae, but the pathogenicity of the strains differed significantly among different temperature regimes, and also among species. The infectivity of $S$. ichnusae to $G$. mellonella last-instar larvae increased with higher temperatures until $25^{\circ} \mathrm{C}$. Our results are in line with those of TARASCO et al. (2015b), who tested isolated strains and found an advantageous higher mortality at $10^{\circ} \mathrm{C}$, and the results of SHAURUB et al. (2015) who studied the effects of ultraviolet (UV) light, temperature, soil type (texture), and soil moisture level on the infectivity of four EPNs used against late third instars of Ceratitis capitata (Wiedemann) where a temperature of $25^{\circ} \mathrm{C}$ gave the highest efficiency of nematodes, while low mortality rates were associated with low temperatures.

The current study demonstrated that $S$. feltiae isolates from Lebanon performed poorly at $10^{\circ} \mathrm{C}$, although mortality at similarly low temperatures were recorded in 
different experiments (GREWAL et al., 1994; TARASCO et al., 2015b) where Steinernema spp. were able to cause mortality on Galleria larvae between $10{ }^{\circ} \mathrm{C}$ and $32{ }^{\circ} \mathrm{C}$. One possible explanation could be that 72 hours were insufficient for $S$. feltiae to kill its host at that relatively low temperature. Higher infection rates might have been obtained by inoculation of EPNs for a longer period as previously shown in other studies (HAZIR et al., 2001; RADOVÁ \& TRNKOVÁ, 2010). However, rapid infection is critical and necessary when it comes to control a relatively dangerous pest. In our study, the highest mean mortality for the tested Lebanese isolates was achieved at $20^{\circ} \mathrm{C}$, while $25^{\circ} \mathrm{C}$ was considered the optimum infestation temperature for the Italian strains. Significant differences between strains of the same species EHB5 (96\%) and EHB4 (33\%) isolated from close geographical areas were also recorded with Lebanese $S$. feltiae strains at $30^{\circ} \mathrm{C}$; similar results were obtained by TARASCO (1997) who tested seven $S$. feltiae strains isolated from various Southern Italian regions. No mortality was recorded at $35^{\circ} \mathrm{C}$ except for $S$. ichnusae ItSSAR4 and H. bacteriophora ItH-LU1 (isolated from Italy), which were $23 \%$ and $37 \%$ respectively. However, the absence of mortality caused by Heterorhabditis sp. BAR8 at $35^{\circ} \mathrm{C}$ is not consistent with what reported in published literature showing satisfactory efficiency at high temperatures (SHAURUB et al., 2015), although H. bacteriophora ItH-LU1 and S. ichnusae ItS-SAR4 were able to tolerate moderately the relatively high temperature and caused $37 \%$ and $23 \%$ respectively larval mortality.

These differences in survival and pathogenicity may be attributed to the climatic origins or the soil habitats of these nematode species (Ulu \& SUSURLUK, 2014). This could be correct in the case of $S$. ichnusae ItS-SAR4 and $H$. bacteriophora ItH-LU1 whose natural habitat is the sea coast and which reached at $30^{\circ} \mathrm{C} 53 \%$ and $74 \%$ mortality respectively. However our results with S. feltiae EHB5, EHB4, EHB1 isolated from mountains in Lebanon does not agree with this model inducing no mortality at a relatively low temperature $\left(10^{\circ} \mathrm{C}\right)$. It can be hypothesised that a variation of $5^{\circ} \mathrm{C}$ could be significant in the microenvironment where the Lebanese $S$. feltiae strains EHB5, EHB4, EHB1 were isolated; consequently they caused almost total mortality at $15^{\circ} \mathrm{C}$. Moreover, MukuKa et al. (2010) showed that the strain's original habitat and environmental conditions do not affect the heat tolerance of EPNs, referring to the minimal fluctuation between soil temperatures. From a different perspective, CHEN et al. (2003) suggested that temperature affects the interaction between the nematode and the host insect, claiming that host cues are not emitted or detected equally at different temperatures. Although the thermal niche of the two families Steinernematidae and Heterorhabditidae have been previously studied, with the first well adapted to cool climates and the second to warmer environments, further studies are necessary. In fact the EPN-host relationship is believed to be affected by temperature and could be critical in determining the real mechanisms involved in the effect of temperature. Therefore a better investigation on this interaction might improve the likelihood of success of EPNs.

\section{ACKNOWLEDGEMENTS}

Research supported by National Council for Scientific Research Lebanon CNRS-Lebanon and University of Bari "Aldo Moro" funds.

\section{REFERENCES}

BEDDING R.A., AKHURST R.J., 1975 - A simple technique for the detection of insect parasitic rhabditid nematodes in soil. - Nematologica, 21: 109-16.

Berry R.E., LiU J., Groth E., 1997 - Efficacy and persistence of Heterorhabditis marelatus (Rhabditida: Heterorhabditidae) against root weevils (Coleoptera: Curculionidae) in strawberry. - Environ. Entomol., 26: 465-470.

Chen S., Li J., Han X., Moens M., 2003 - Effect of temperature on the pathogenicity of entomopathogenic nematodes (Steinernema and Heterorhabditis spp.) to Delia radicum. - BioControl, 48(6): 713-24.

DunPHY G.B., WeBSTER J.M., 1986 - Temperature effects on the growth and virulence of Steinernema feltiae strains and Heterorhabditis heliothidis. - J. Nematol., 18: 270272.

EHLERS R.U., 2001 - Mass production of entomopathogenic nematodes for plant protection. - Applied Microbiology and Biotechnology, 56 (5-6): 623-33.

Grewal P.S., Selvan S., Gaugler R., 1994 - Thermal adaptation of entomopathogenic nematodes: niche breadth for infection, establishment, and reproduction. - J. Therm. Biol.,19(4): 245-53.

Grewal P.S., De Nardo A.B., Aguillera M.M., 2001 Entomopathogenic nematodes: potential for exploration and use in South America. - Neotropical Entomology, 30:191-205.

Griffin C., Downes M.J., 1991 - Biogeography of entomopathogenic nematodes. - Annual Meeting of the Society for Invertebrate Pathology, 24: 59-60.

GRIFFIN C.T., 1993 - Temperature responses of entomopathogenic nematodes: implications for the success of biological control programmes. In: Nematodes and the Biological Control of Insects, Bedding H., Akhurst R., Kaya R. Ed., CSIRO, East Melbourne, Australia, pp. 15-126.

Hazir S., Stock P., Kaya H., KoppenhöFer A., Keskin N., 2001 - Developmental temperature effects on five geographic isolates of the entomopathogenic nematode Steinernema feltiae (Nematoda: Steinernematidae). - J. Invert. Pathol.,77: 243-250.

KAYA H.K., 1977 - Development of the DD-136 strain of Neoaplectana carpocapsae at constant temperature. Journal of Nematology, 9: 346-349.

Kung S., Gaugler R., Kaya H. K., 1991 - Effects of soil temperature, moisture, and relative humidity on entomopathogenic nematode persistence. - J. Invert. Pathol., 57(2): 242-49.

Lacey L. A., Grzywacz D., Shapiro-Ilan D.I., Frutos R., Brownbridge M., Goettel M.S., 2015 - Insect pathogens as biological control agents: back to the future. - J. Invert. Pathol., 132: 1-41.

MolyneuX A.S., 1985 - Survival of infective juveniles of Heterorhabditis spp., and Steinernema spp. (Nematoda: Rhabditida) at various temperatures and their subsequent infectivity for insects.- Rev. Nematol., 8: 165-70.

MolyneuX A.S., 1986 - Heterorhabditis spp. and Steinernema spp.: temperature and aspects of behaviour and infectivity. - Exper. Parasitol.,62: 168-80.

Mukuka J., Strauch O., Waeyenberge L., Viaene N., Moens M., Ehlers R., 2010 - Heat tolerance among different strains of the entomopathogenic nematode Heterorhabditis bacteriophora. - BioControl, 55: 423-434.

Noujeim E., SaKr J., Fanelli E., Troccoli A., 2016 Phylogenetic relationships of entomopathogenic nematodes and their bacterial symbionts from coastal areas in 
Lebanon. - Redia, 99: 127-137. http://dx.doi.org/10. 19263/REDIA-99.16.16

PoINAR G.O., 1990 - Taxonomy and biology of Steinernematidae and Heterorhabditidae. In: Entomopathogenic Nematodes in Biological Control, Gaugler R.D. \& Kaya H.K., Ed., CRC Press, 23-61.

RADOVÁ Š., TRNKOVÁ Z., 2010 - Effect of soil temperature and moisture on the pathogenicity of two species of entomopathogenic nematodes (Rhabditida: Steinernematidae). - Journal of Agrobiology, 27(1): 1-7.

Rutherford T.A., Trotter D., Webster J.M., 1987 - The potential of heterorhabditid nematodes as control agents of root weevils. - Can. Entomol., 119: 67-73.

Shapiro-Ilan D., Gouge D., Piggott S., Patterson Fife J., 2006 - Application technology and environmental considerations for use of entomopathogenic nematodes in biological control. - Biological Control, 38:124-133.

Shaurub E.H., Soliman N.A., Hashem A.G., AbdelRAHMAN A.M., 2015 - Infectivity of four entomopathogenic nematodes in relation to environmental factors and their effects on the biochemistry of the medfly Ceratitis capitata (Wied.) (Diptera: Tephritidae). Neotropical Entomology, 44(6): 610-18.

Tarasco E., Clausi M., Rappazzo G., Panzavolta T., Curto G., Sorino R., Oreste M., Longo A., Leone D., Tiberi R., Vinciguerra M.T., Triggiani O., 2015a Biodiversity of entomopathogenic nematodes in Italy. Journal of Helminthology, 89 (3): 359-66.

TARASCO E., Triggiani O., 1997 - Survey of Steinernema and Heterorhabditis (Rhabditida: Nematoda) in Southern Italian soils. - Entomologica, Bari, 31: 117-23.
Tarasco E., Oreste M., Xingyue Li., Qizhi LiU., 2015b Infectivity of mediterranean native entomopathogenic nematodes (Steinernematidae and Heterorhabditidae) from natural habitats in relation to temperature. - Redia, 98:109-114

TARASCO E., 1997 - Confronto di patogenicità fra otto ceppi di Steinernema feltiae (Filipjev, 1934) (Rhabditida: Steinernematidae) rinvenuti in terreni dell'Italia meridionale. - Entomologica, Bari, 31: 171-79.

Ulu T.C., SusurluK I.A., 2014 - Heat and desiccation tolerances of Heterorhabditis bacteriophora strains and relationships between their tolerances and some bioecological characteristics.- Invertebrate Survival Journal, 11:4-10.

White G.F., 1927 - A method for obtaining infective nematode larvae from cultures. - Science, 66: 302-303.

WRIGHT P.J., 1992 - Cool temperature reproduction of steinernematid and heterorhabditid nematodes. - J. Invert. Pathol., 60: 148-151.

Yeo H., Pell J.K., Alderson P.G., Clark S.J., Pye B.J., 2003 - Laboratory evaluation of temperature effects on the germination and growth of entomopathogenic fungi and on their pathogenicity to two aphid species. - Pest Manag. Sci., 59: 156-165.

Zervos S., Johnsosn S.C., Webster J.M., 1991 - Effect of temperature and inoculum size on reproduction and development of Heterorhabditis heliothidis and Steinernema glaseri (Nematoda: Rhabditoidea) in Galleria mellonella. - Can. J. Zool., 69: 1261-1264. 
128 - Blank Page 